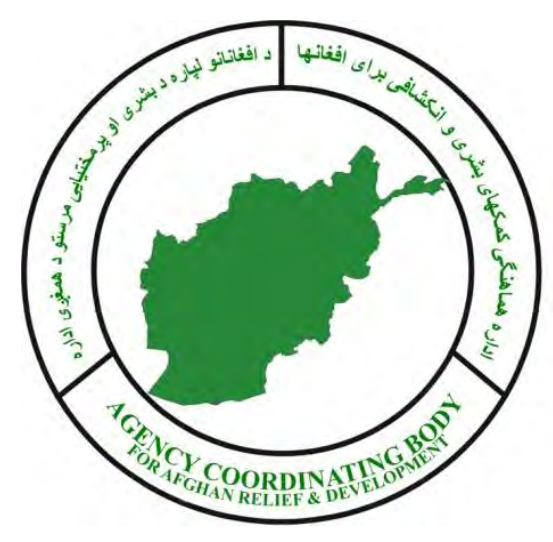

\title{
ACBAR Workshop for Donors, NGO Coordinating Bodies and Civil Society
}

\section{European Union Kabul}

\section{December 2015}

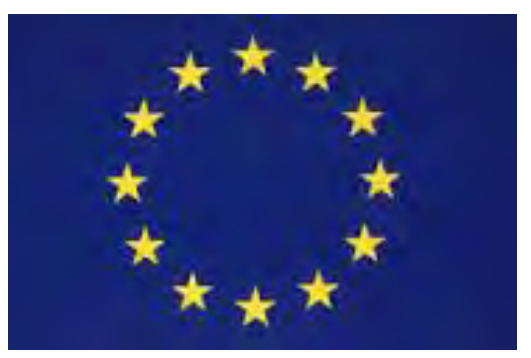

On the 17th December 2015, ACBAR and the EU hosted a donor workshop for ACBAR and fellow coordination bodies (ANCB, ASCF, AWN and SWABAC). The workshop provided a forum for donors to present their funding opportunities and engage with NGOs and civil society representatives. During the workshop there was a presentation of the

Mutual Cooperation Mechanism, also referred to as Memorandum of Understanding, signed between the Government and the Civil Society Joint Working Group in September 2015, and a discussion on the role of civil society in the run up to the Brussels ministerial conference in 2016. 


\section{Contents}

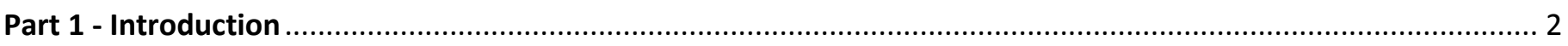

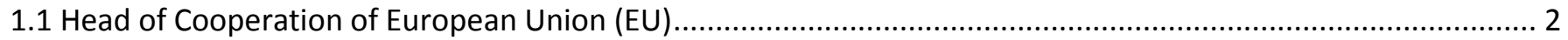

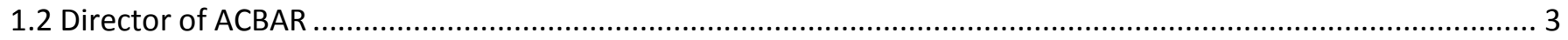

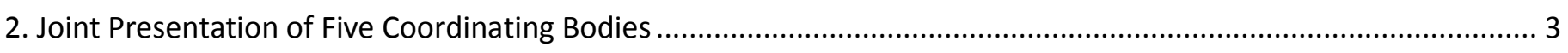

2.1 Key Issues affecting NGOs and CSOs raised by Coordinating Bodies........................................................... 5

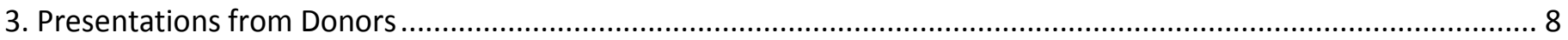

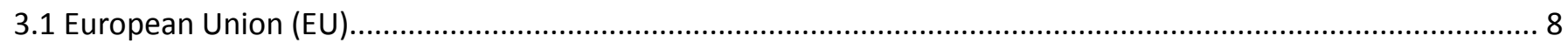

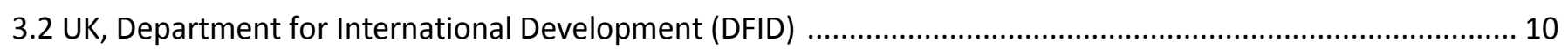

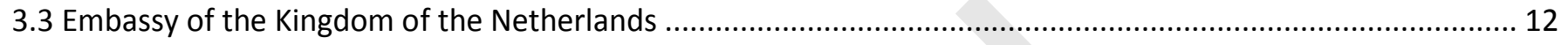

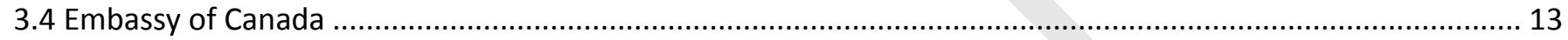

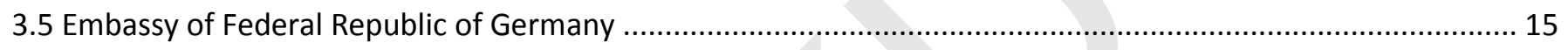

3.6 USAID's Office of Democracy and Governance (ODG), Afghan Civic Engagement Program (ACEP) .................. 17

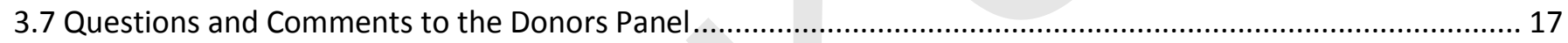

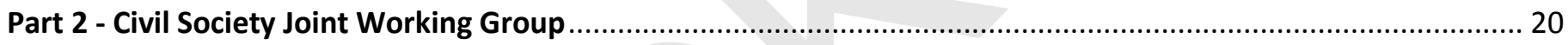

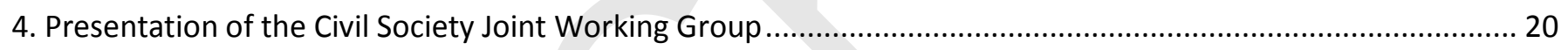

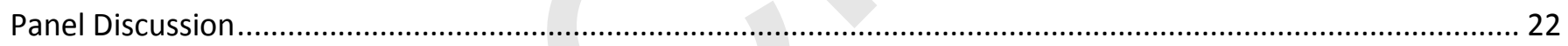

Annexes - Donor Information and Participant Lists

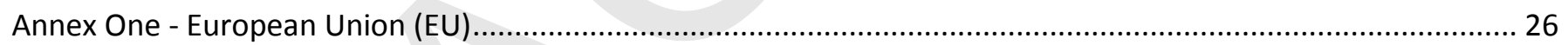

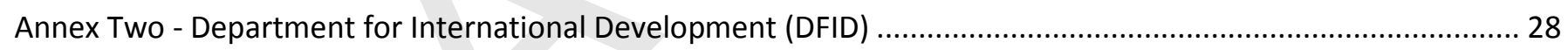

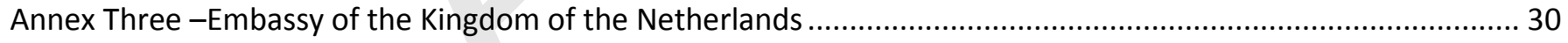

Annex Four - Embassy of Canada - Global Affairs Canada ............................................................................ 32

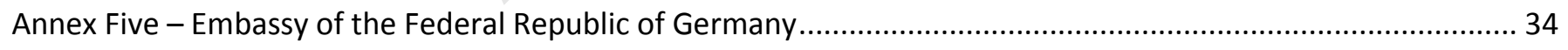

Annex Six - United States Aid for International Development (USAID) …...................................................... 36

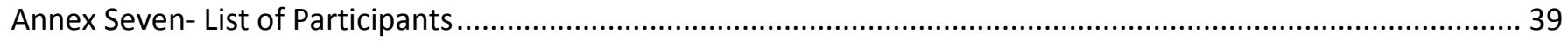




\section{Part 1 - Introduction}

The workshop was divided into two sessions: the first session included a presentation by ACBAR and other Coordination Bodies, followed by presentations by different donors that support Non-Governmental Organizations (NGOs) and Civil Society Organizations (CSOs) and questions and answers. The second session consisted of a presentation by the Civil Society Joint Working Group (CSJWG) on its activities and the Mutual Cooperation Mechanism (MCM) agreement signed between the government and CSJWG. This was followed by a panel discussion with CSJWG members and a representative from the President's Office.

\subsection{Head of Cooperation of European Union (EU), Maurizio Cian}

I would like to thank everyone for attending the workshop and ACBAR for organizing this workshop for donors and civil society. ACBAR is a long standing partner of the EU. This is a very good opportunity for civil society to get together; it is useful for us to have one partner and for civil society to speak with one voice. Afghanistan is a priority for the European Union and it is the country with which we have our largest bilateral cooperation-1.4 billion Euros over 7 years, more than 200 million Euros annually.

The EU remains a strong supporter of civil society and a substantial part of our cooperation is implemented by NGOs/CSOs. Civil society in Afghanistan is providing services, for example in health. The role of civil society is also to have an oversight of what the government is doing and to make the government as accountable and effective as possible. Strong civil society means normally results in good governance and better delivery of public services. This is what we want to encourage in the civil society. In 2015, we finalized the EU Roadmap for Engagement of Civil Society in Afghanistan, and we thank those who contributed to the consultations, over 130 civil society organisations, including some of those present today. This roadmap sets the objectives of not only the EU but also its members for future engagement with civil society. Our support of course is financial but it is also political. We want to have partnership, especially on some issues, with the government to make the government closer to the citizens and more effective in respect of their action.

We have an important event next year for Afghanistan, the Ministerial Conference being held in Brussels on $4^{\text {th }}$ and $5^{\text {th }}$ October, 2016. It will be the occasion for the international community to renew support for Afghanistan, possibly financial, at the same level as in the past but as you know there are many other issues in the world so I think the financial effort had to be shared. Civil society will play an important role towards the preparation of the conference. I do not know how many people we will be able to invite to Brussels next year, but the important work will be done beforehand. Mario will lead this process for the EU and he will be our focal point. For those who will have a chance to be invited to Brussels, it would be good to meet before. 


\subsection{Director of ACBAR, Fiona Gall}

I would like to welcome the participants to the workshop and thank the EU colleagues for hosting this event. This is a useful opportunity for us to meet the donors who cannot easily leave their offices. From our perspective as members of civil society, this is a very challenging and also a rewarding time to work in Afghanistan. We have never had in fact such a young and educated population. We have very good communications - mobile phones, internet and a vibrant local media. We now have so many possibilities to promote dialogue between ourselves. When we compare this to the last 30 years, we can say that civil society now has much more space. A good indication is the recent peace march in Kabul protesting against the death of the Hazara civilians in the south which brought together all different sections of the community. On the radio and local television every day you can hear people talking and putting forward ideas. So the dialogue is everywhere and in the provinces, local radio stations and local media in the provinces. The voice of civil society has never been so vibrant.

On behalf of NGOs, ACBAR has held donor conferences in the past two years ${ }^{1}$. This year we wanted to make it slightly different so ACBAR had asked other Coordinating Bodies who work with civil society organisations to share in the discussions today and to promote closer collaboration with international donors.

\section{Joint Presentation of Five Coordinating Bodies}

Agency Coordinating Body for Afghan Relief and Development (ACBAR) - Mr. Amanullah Jawad - Chairman

- 1988 - established in Peshawar, Pakistan

- 142 members - 70 national, 72 international

- Key functions - platform for sharing information and representation, advocacy, regional coordination, capacity building activities

- Donors: DFID, Tawanmandi, Japanese NGOs, membership fees, website fees

- Members sectors: education, health, NSP, livelihoods, agriculture, gender, disability, human rights, livelihoods, on budget and off budget in all provinces

- Range of budgets of individual members: 20,000 USD - 6 million USD

- 2014 budget: 625,000 USD $^{2}$

Afghan Civil Society Forum Organization (ACSFO) - Mr. Ahmad Seyar Lalee

- 2002 established in Kabul

- 183 members

- Key functions: Coordination and Networking; Advocacy, Capacity building, Public outreach

- Donors: EU, USAID, GIZ, OXFAM-NOVIB, OXFAM-GB, UNDP, UNOPS,

- Members sectors: Advocacy, Coordination, Networking, Capacity building, Research and Public outreach

- 2014 budget: 3 million USD ${ }^{3}$

\footnotetext{
${ }^{1}$ See ACBAR Donor Conference reports 2013-15, available at http://www.acbar.org/files/downloads/Donor\%20Workshop\%20III\%20to\%20print.pdf or http://www.acbar.org/Advocacy/

2 ACBAR Civil Society Report, 2015
} 
Afghan NGOs Coordination Bureau (ANCB) - Mr. Baryalai Omarzai - Executive Director

- Established in 1991 in Peshawar, Pakistan

- 210 National NGOs

- Key functions: cooperate and coordinate in the development, growth and welfare of activities of Afghan NGOs, secure relations with international organizations, donor agencies and government and build the capacity of its members and non-member NGOs,

- Donors: Japanese NGOs, ODA (JAPAN), membership fees

- Member sectors: Education, Health, Livelihoods, Agriculture, Advocacy and small scale construction projects

- 2014 budget: 200,000 USD

Afghan Women's Network (AWN) - Mr. Ahmad Fahim Hoshmand - Programme Manager

- Started in 1995 in Peshawar, Pakistan

- 130 NGO members, 3500 individual members.

- Key functions: Women's Political participation, Women's peace and security, Women's legal and social protection.

- Donors: DFAT, Tawanmandi, UNOPS, UN-Women, Womankind, Cordaid, Finnish Embassy, Norwegian Embassy, membership fees.

- Member sectors: Advocacy, Health, Education, Research, Legal Resource Centers, Human's rights, Women's Rights, Awareness, Capacity building, Gender, Handicrafts, Women's Empowerment

- 2014 budget: 2 million USD ${ }^{4}$

South West Afghanistan and Baluchistan Association for Coordination (SWABAC) - Mr. Jan Mohammad, Coordinator

- Started in 1988 in Quetta, Pakistan

- 55 members

- Key functions: Coordination among assistance agencies, Advocacy, Capacity Building

- Donors: UN, Inter news /USAID, AusAid

- Member sectors: Health, Wash, Emergency, Community Empowerment, Education and Peace building

- 2014 Budget: 61,500 USD $^{5}$

- Member of CS-JWG , CoST (Construction Transference Initiative), CPG (Civilian Protection Group), AICS(Afghan Institute of Civil Society) and PDC (provincial Development Committee)

\footnotetext{
${ }^{3}$ ACBAR Civil Society Report, 2015

${ }^{4}$ ACBAR Civil Society Report, 2015

${ }^{5}$ ACBAR Civil Society Report, 2015
} 


\subsection{Key Issues affecting NGOs and CSOs raised by Coordinating Bodies}

\section{Current Context - Government}

The government has lobbied successfully to have more donor funds channelled through the government as "on budget" donations. This has led to a decline in direct funding to NGOs/CSOs and thus to greater competition for declining resources. International funding for Afghanistan has decreased in the last year since the departure of NATO forces, and with different problems in the world, Afghanistan is no longer the only priority conflict affected area. So we have to have close relations with government, but sometimes these relationships are not easy. We continue to provide many services, for example in health, education agriculture and the national solidarity programme, but sometimes there are issues of how much involvement we have in the preparation of these programmes and real consultation on policy levels. This can be an indication of lack of trust with some of the different government Ministries and ourselves, there is not enough sharing. NGOs/CSOs also face increasing bureaucracy; we have a lot of reporting to do; to our line Ministry (Ministry of Economy), and different sector Ministries. Memorandums of Understanding (MoUs) have to be established for each project and can take time to authorize. This is not an easy process although we have good relations on local levels with provincial directorates. The process is different for each organisation and each Ministry so it is not across the board but there are blockages. We also notice that we are expected to deliver projects without much consultation and there is less inclusion of NGOs/CSOs in providing ideas and planning new government initiatives. In this context we need to redefine ourselves as NGOs and CSOs and ask ourselves - what should be our role and how we should continue? Many of us have already started these discussions to review our priorities and to see how we can change ourselves.

\section{Comparative advantages of NGOs/CSOs}

NGOs/CSOs in Afghanistan have a long history working in different sectors, working in remote areas, working with local communities and including local communities in discussions and planning. For this work we have adopted participatory and rights based approaches. NGOs/CSOs are responsive to different issues and needs - humanitarian disaster, specific local needs and work with vulnerable groups such as youth, women and persons with disabilities. We engage in civic education, literacy and environmental issues. We cover a broad range of interests and expertise.

\section{Challenges faced by NGOs/CSOs}

There is an imbalance between national NGOs/CSOs and international NGOs/CSOs. Although there are now various coordination mechanisms, coalitions and platforms for NGOs/CSOs to work together, this could be improved for many national NGOs/CSOs who find it difficult to access partnerships and donor funds compared to international NGOs/CSOs. Even though national NGOs/CSOs are working at grass roots in many provinces and in difficult environments, where international colleagues cannot go, they still do not necessarily get the support they need.

Another problem for us is that as a group we still have limited capacity; we have done a lot of training and capacity building in the last 15 years but budgets are often short term so we do not have enough time to establish capacity. We have to constantly retrain new staff as we lose staff to government, UN and other organisations. We have to constantly rebuild ourselves. 
Sometimes we are not able to implement large programmes; we are not able to scale up. So we do have a better educated population now and we can utilize that but we need to develop professionally and develop more technical expertise.

\section{Potential Solutions with the Government}

It is good to have representatives of the government here today. We need to continue to lobby and be present in policy meetings on different levels with government on behalf of the wider NGO/CSO community, to represent others and not just our own interests.

The Coordination Bodies have a special responsibility to represent the wider group. This is the time now for civil society actors to share experience and learn from each other. We also want to show examples of best practice to government and donors. We see a lot of reports written and put on shelves and in fact we would like to have much more dialogue about what has been successful.

The other big issue is corruption; none of us have been perfect in the face of corruption. We need to make a clear decision now and say that as NGOs/CSOs that we will not contribute to corruption. We will start from ourselves and improve ourselves and not contribute to corruption around us.

\section{Potential Solutions with Donors}

There has been an increase in different types of partnerships and coalitions between donors and national and international NGOs/CSOs in the last few years. This leads to a range of possibilities which is potentially more creative and a better way for us to learn. So we need to makes sure that everyone has at least some access to initiate new projects and new ideas. We do not want always to have the same actors but a range of actors so that we have flexibility in order to initiate new ideas and new partnerships. The duration of project periods is always an issue, because a short-term project is very hard to show the impact and real results, so we would recommend that donors give longer term funding (3-5 years) in order for-organisations to build their capacity. One of the useful things we have seen is that some donors are prepared to give feedback on proposals and projects. We need to have lessons learned. We need to sit down and see what the donor processes are and how we can feed into that, as coordinating bodies, and share the knowledge in order to improve not only proposal writing but also programmes and projects. Some of our colleagues have suggested that we need to link more closely to the private sector for sponsorship. The private sector is also finding it difficult to operate in the current environment but some links have been created and this is a good step to look for sustainability, so we need to long at new ways of finding support in the private sector. We also need to improve transparency and accountability through mechanisms such as Integrity Watch's social audits, where local community is verifying the work and monitoring outputs. We need to involve the community more.

These are some of the ideas from our recent meeting of the five Coordinating Bodies which we have shared with you and we look forward to your questions and comments. Thank you very much.

\section{Comments and Questions:}

- $\quad \mathrm{NGOs/CSOs}$ are working at grass root level in very remote areas and therefore have established good relations with the local communities and villages. Civil society is working as a bridge between people and 
government and donors; we should be supported because we are working on the grass root level and we are close in contact with the people to identify the real needs. We have 210 Afghan NGO members at ANCB over the country and we are busy in every area of activity. The donor community should therefore support NGOs/CSOs. In most government programmes like NSP or NSDP, or international programmes, at the last stage of the programme, the implementers are the NGOs.

- In the past there were many problems between the government and civil society. The government also criticized NGOs for spending a lot of money. Now, fortunately, both donors and government accept the role of civil society and NGOs. NGOs/CSOs are part of the community and should be supported.

- The current mass migration of people from Afghanistan is also an issue. NGOs/CSOs should be supported to be active in this area and work against the underlying drivers of migration, for example livelihood creation.

- NGOs have less funding. For example, in SWABAC, during the time of the Taliban, we had 80 members and most were active but now only 20 or 25 have projects. There is now a good opportunity for the Afghan people, the government and the donors to accept the role of civil society in the community and ensure access to funds for smaller NGOs.

- According the presentations of Coordinating Bodies, some of them have core funds but some of them do not. What is the difference and why is it like this? Core funds should be the same for all coordinating bodies, there should be balanced development and donors should think about this.

- Coordination efforts benefit NGOs by helping, for example, to prevent non-duplication of activities and ensuring that your NGO views are represented in policy discussions (such as vulnerable populations and gaps in the response). It is therefore suggested that the donor community should allow for NGOs to have room in their budgets for membership of coordinating bodies.

\section{Answer:}

- At Afghan Women's Network we have core funds from our donors in line with our strategic focus areas. During our proposal writing we do our best to involve our member organisations in implementing. At AWN we do not implement projects ourselves; we are just a monitoring body. We do fund-raising for our members as well. Core funds are not just given to the network in Kabul for its own admin costs. We have regional offices in eight different zones. Each zone covers several provinces. In each province we have our focal points and we coordinate research programmes - we have researchers and we do our best to involve our partners and give them funds and objectives for research. We provide them opportunities and we try to be a source of funds for our members. But in each area that we operate we have programme activities, for the research we have network meetings; we have coordination meetings, consultations with provincial officials and our members. So these core costs are not just for admin costs, a very short and specific amount is for admin. We have to pay for rent, for staff, for coordination focal points, for transport, accommodation, for advocacy teams. So $85 \%$ of the budget is for programme costs and only about $10 \%$ is estimated for core funds.

\section{Comment:}

- This is challenging issue for Afghan civil society and for Afghan NGOs/CSOs, there is no balance. Only Tawanmandi has a few core partners, but what about the rest? ANCB has no core funds, SWABAC has no core funds, and few Afghan NGOs have core funds. This is a challenging issue and should be considered. 


\section{Presentations from Donors}

\subsection{European Union (EU) - Mario Varrenti}

\section{Current support}

When it comes to EU funding we provide funding on a competitive basis procedure, or "calls for proposals", managed locally in Kabul and globally from Brussels, so we do not support unsolicited requests for funding. In 2015, the EU has 67 grants managed by NGOs/CSOs, for a total amount of EUR 100 million managed in different areas of cooperation in Afghanistan.

The average grant size is 1.5 million EUR but this varies on the instruments we use - those for strengthening civil society and human rights advocacy we have lower thresholds (EUR 700,000 under CSO-LA and EIDHR). We have an imperative from headquarters like many donors to manage less and less contracts which, by default, are bigger and bigger. So we need to find some way around this. We also provide indirect support to NGOs and civil society through other programmes which we do not manage directly; like health for example, or the NSP or the new future local governance programme which also foresees a civil society component.

If you look at the grants that we manage directly, you can see roughly three-quarters are in the areas of service delivery (ranging from agriculture, to social services, health etc.) and a quarter is in human rights, women's rights, advocacy and accountability. We have also been very transparent about the nationality of our grantees - $80 \%$ of grants is managed by INGOs, while $19 \%$ by national NGOs. This is something that we are trying to address. The figure is of course different if we look at the co-applicants in our applications. There we have a reversed balance in terms of nationality. One of the recommendations that came during the consultations from the civil society road map earlier this year was to work more directly with Afghan NGOs. We have taken this seriously and starting from the calls launched this year we have created incentives or positive discrimination for Afghan NGOs. We have seen this producing some results and some of the old partnerships reversing or with Afghan partners more in the lead. Out of the contracts awarded in the last two calls for proposals launched after the CSO Road Map we can see 55\% of grants are with Afghan NGO partners in the lead.

\section{CSO Roadmap and Future Plans}

The EU Roadmap for Engagement of Civil Society in Afghanistan was an exercise that we conducted earlier this year with over 130 CSOs, many represented today in this room. There were a few key priorities that will inform our future support to civil society:

1) The first one is to consult more when we define our programmes - for the civil society programme for next year we have launched an online consultation trying to take this recommendation into account in the way we work;

2) Another recommendation is to reach more to grassroots organisations beyond Kabul. We have pressure to work with bigger and bigger contracts but we are trying to explore sub-granting as an option for our future support to civil society. At the moment we are conducting a study to understand how sub-granting has been used in our previous grants and inform us and give us some recommendations on how to make more use of it in the future programmes that we will launch next year; 
3) Another recommendation is to make performance more evident, along the lines of sharing what works and what does not work. One idea that we are looking at is to make results of monitoring and evaluation a source of public good for everyone to share. Therefore, we are looking into online platforms options that we can use. This is work in progress. Hopefully in a year from now this will be a reality for us at the EU;

4) Our interventions should be more sustainable interventions and can produce results beyond the life span of the programme. One way is to make the programmes with longer time frames rather than 2-4 years project durations, this is something we are looking at. As well we want to solicit information on number of volunteers involved in the action and reward these sorts of opportunities;

5) Of course to improve coordination between donors is something that comes regularly and not only in the area of civil society support;

6) Last but not least, one of the strongest recommendations was to work to strengthen ability of civil society in monitoring and to holding government to account for services. We have taken this seriously. In the last call for proposals for 2 million that we launched, we had community based monitoring as one of the key objectives.

To see the roadmap for engagement of civil society in Afghanistan visit the link below.

http://www.eeas.europa.eu/delegations/afghanistan/documents/eu afghanistan/2015-9-6-eu-roadmap-forengagement-with-civil-society-in-afghanistan-final en.pdf

\section{Common Mistakes in EU proposals}

We are a bureaucratic organisation but we can do better and we want to avoid some of the common mistakes made in applications that we receive. Out of 73 applications in the two most recent calls, 31 (42\%) were rejected. The seven top mistakes were:

- Less than the minimum or more than the maximum funding limits (8) $\mathbf{- 1 1} \%$

- Exceeding co-funding levels (8) $-\mathbf{1 1} \%$

- Missing documents in application (7) $-9.6 \%$

- Failure to include a co-applicant. This has always been encouraged and recently co-application has been made compulsory (5) $-6.8 \%$

- Less than minimum or more than maximum project duration limits (1) $\mathbf{- 1 . 4} \%$

- Failure to upload documents in the PADOR system. We try to avoid this by sending reminders to the applicants.(1) - $\mathbf{1 . 4} \%$

- Mistake with simplified costs/lump sums (1) $-\mathbf{1 . 4} \%$

\section{A new online application system}

With the problems also come some solutions. As of July this year the EU will move to a paper-free and online application system called Prospect. This is a solution is good for the environment and will minimize human mistakes in application, as the system will not permit them and will block the application. It is strongly recommended to visit this website and there is an e-learning training on how to use this system. As of July last year this is compulsory and there are no more applications in the old system, both local and global. https://ec.europa.eu/europeaid/prospect. 


\subsection{UK, Department for International Development (DFID) - Liz Fajber}

\section{UK Support to Civil Society in Afghanistan}

It is a great pleasure to be here and thank you for the invitation. I am struck by the wealth of experience in the room and that there are many organisations here who have been working on these issues for a long time, much longer than the time scales than the UK has been supporting civil society in Afghanistan. In the last ten years, though, we have seen the tremendous increase in capacity and advocacy and strength of civil society in Afghanistan. I will share briefly what we are doing to support civil society and where future support is going and also share some of the lessons and tips that might be useful for new programme development.

\section{Tawanmandi (2011-2017, £33.78m, UK contribution $\mathbf{f 1 9 . 9 5 m ) ~}$}

Our flagship programme for support to civil society is the Tawanmandi programme which has been running since 2011 and will run until July 2017. This programme has reached over 80 NGOs as direct partners both with project grant and core grants. Thematic areas include anti-corruption, access to justice, peace building, media and human rights. Also the programme has had a strong emphasis on organisation and capacity building. Sector core working groups have been established to coordinate organisations working on similar themes and to share lessons and strengthen advocacy. Many of you know our Tawanmandi colleagues who are present here today so please contact them for more questions. Moving forward the management of Tawanmandi is transitioning from British Council to DFID in the last 18 months of the programme, and there will be an additional component of technical assistance to strengthen technical capacity and advocacy around those thematic areas supported by Denmark.

\section{Humanitarian Programme (2014-2018, f80m)}

In our humanitarian programme we support international and Afghan NGOs. One component on capacity building which ACBAR $(\mathrm{f} 2 \mathrm{~m}$ ) is leading is reaching 40 Afghan NGOs and strengthening co-ordination and their engagement in the humanitarian system. A second component is the Resilience Consortium led by Afghan Aid which includes INGOS and partners, national NGOs, for service delivery in Northern areas.

Finally, there is the Common Humanitarian Fund (CHF), which supports service delivery in emergency contexts. Support to NGOs is approximately half to INGOs and half Afghan NGOs. There is a real desire to increase this ratio so that there is more delivery by Afghan NGOs in the future and that is something the programme is looking to address.

\section{Girls Education Challenge Fund (2013-2017, f49.5m)}

The UK also supports the Girls Education Challenge Fund, involved in strengthening community based education for girls and boys in marginal areas. It is primarily being implemented by INGOs (4 sub-projects) but very much in partnership with communities at the local level. This includes establishing community school management committees (over a thousand at the moment) to strengthen community based engagement and participation.

\section{Afghanistan Reconstruction Trust Fund (ARTF)}

We are very substantive donors to the ARTF fund which also has a number of service delivery areas (ie. health, education, NSP). 


\section{Women's Rights Programming}

I want to also flag our programming on women rights where we support INGOs and Afghan NGOs on programmes on prevention of violence against women, protection and response; also women's economic empowerment. Human Rights and Democracy Fund

Some of you might be aware of the UK Human Rights and Democracy Fund, this is a global Fund which is accessible and available to national NGOs, with the calls for proposals online and bids online and we have provided support to Afghan national NGOs.

All of these programme as on-going programmes at the moment.

\section{New programmes}

In terms of additional work we are looking at programming to strengthen civil society capacity and advocacy in some select areas (likely to be Security Sector, Extractive Industries) based on the existing programming we have and issues that we have identified. We are seeking to strengthen donor coordination on civil society in order not to duplicate other programmes, such as new EU funding for civil society.

Human Rights Democracy Fund - Calls for proposals for this fund have not been issue for next year as of yet. We will circulate more information on this when available. EU programming for civil society - The UK is a key contributor to the EU, and we are working closely with the EU to support the development of their new programme of support for civil society. Policy - On the policy side we want to support and work with civil society and the government to prepare for Warsaw and Brussels and to be sure that there is the space and mechanism for civil society to engage. We look forward to working with you and suggestions in how we can do that best.

\section{Lessons for future support for Civil Society}

Some reflections and lessons from previous programmes that may be useful to you for your organisation's development:

Strengthening organisational capacity is very important. This includes a number of issues:

- Capacity for financial management and control, and issues of transparency and accountability. Capacity for strategic planning and advocacy having a clear plan for sustainability and business planning.

- Importance of having clear Monitoring and Evaluation systems and capacity in place

Opportunity of collaboration and co-ordination within sectors for wider impact/advocacy: Another lesson is the need to move beyond individuals and individual organisations to collaboration and co-ordination. One lesson that has come out from other work globally is that it works most effectively when there is a specific policy or agenda to work around. Sometimes it is very difficult to coordinate for coordinating sake but where there is a specific output or deadline or policy that can help to galvanize people to work together.

- Differential needs and capacity of smaller, rural organisations: Another issue is the need to reach smaller rural organisations that do not necessarily have the skills to write proposals Sub-granting is one mechanism. The coordinating bodies can also provide support and reach out to those sorts of 
organisations. Security challenges and costs: One issue not yet mentioned today is the additional planning and costs of security. This should be included in organisational plans and programme planning.

- Need for stronger donor coordination - there needs be improved coordination to prevent duplication and for better impact and we have been striving for this but we are aware that more could be done.

\subsection{Embassy of the Kingdom of the Netherlands, Somaia Nezami}

We have two sources of funding for civil society actors and NGOs. One is provided directly by the Ministry in the Hague (central funding) e.g. Reconstruction Program, FLOW and Addressing Root Causes Fund, and the other is provided and managed by the Dutch Embassy in Kabul.

\section{Embassy's Fund}

The Dutch Embassy in Afghanistan has its own focus area to support the development goals of the Netherlands just like other embassies/missions. Current Focus area had been narrowed down in 2014 to the field of security and the rule of law, with special attention for women's rights and gender. We believe the civil society organisations in Afghanistan and Dutch co-financing partners will play an important role in implementing projects within the mentioned-above focus area. On a technical note: proposals can be submitted throughout the year but we can only consider between September- December as this is when we are planning funding for the next year. This does not need to be Dutch NGOs but we prefer grouped funding for a larger amount of 2-3 million Euros per project.

Hence besides supporting programs executed by UN agencies like ELECT, EVAW special fund, APRP, we support Dutch INGOs and Afghan and international CSOs like APPRO, CORDAID, Equality for Peace and Democracy (EPD), and Asia Foundation (TAF). For all of them capacity development for the implementer and sub-contracting CSOs are included as a substantial component.

With the completion of the Dutch Reconstruction mission in Uruzgan, the Netherlands has started integrated police training mission in Kunduz. Hence we have preference for all Northern provinces in particular Kunduz.

Also just like DFID we look forward to contributing to the EU funding programmes for civil society in 2016.

Central Funding: There are different thematic frameworks. Of them the following are important:

\section{Reconstruction Tender (2012-2015)}

This will finish in a few days. The main aims under Reconstruction Tender are improving human security in relation to public safety and security, legitimate government, and peace dividends.

\section{Funding Leadership and Opportunities for Women-FLOW (2016-2020)}

The programs funded by FLOW aim to create opportunities for women and girls and foster a transformation towards an enabling environment in which women's rights are better protected. At both local and national levels the programs will contribute to sustainable, inclusive development and to fight against poverty and the lack of equal rights for women and girls. 
Of the nine selected programmes, one programme Women for Women International (Wow) program "Engaging women as agents of change against gender-based violence and poverty" will be implemented in Afghanistan.

\section{Addressing Root Causes Fund (2016-2021)}

The Ministry of Foreign Affairs will introduce a NGO-fund (125 million Euros) aimed at addressing root causes of instability, conflict and forced migration for a group of countries including Afghanistan.

A call for proposals will be published on the MoFA website in January indicating all required documents. The fund will be open for Dutch, International and Afghan NGOs.

Until the date of publication, the embassy will not provide any further information.

\section{Nuffic Tailor Made Training (TMT)}

Program offered as part of the Netherlands Fellowship Program (NFP) run by Nuffic, the Netherlands organization for international cooperation in higher education. NFP promotes capacity building by providing training and education for professionals in development countries including Afghanistan. A tailor-made training course is designed to meet specific needs of a requesting organization. The TMT is specifically meant to enhance the overall functioning of an organization by training a selected group of its staff members.

The program is open to a broad range of organizations in 51 NFP countries, from education institutions, research institutes and ministries to NGOs and small and medium-sized enterprises (SMEs). Afghan NGO's or Afghan government or education organizations (i.e. MoJ, AIBA, SC, AGO, universities, local partner organizations), do qualify for the program. It is open for applications in the field of security and rule of law, with special attention for women's rights and gender.

To obtain more information on how to apply for the Embassy's fund, please contact kab@minbuza.nl

\subsection{Embassy of Canada, Nasir Ebrahimkhail}

Good morning, I would like to give you an overview of what funding mechanisms we have in Afghanistan for civil society organisations.

\section{Funding for International Development Projects - Global Affairs Canada}

Good morning, I would like to give you an overview of what funding mechanisms we have in Afghanistan for civil society organisations.

\section{Funding for International Development Projects - Global Affairs Canada}

Global Affairs Canada is the new name for our department - previously known as the Canadian International Development Agency (CIDA) and more recently Department of Foreign Affairs, Trade and Development (DFATD). Our overall funding amount is $\mathbf{2 3 0}$ million Canadian dollars for the next three years, our country programme strategy for Afghanistan is from 2015-2017. This is the overall amount that is allocated for Afghanistan and the four priority 
areas are: health, education, humanitarian assistance or emergency response and also human rights and women rights.

We are also an important member of the Self Reliance Mutual Accountability Framework (SMAF) ${ }^{6}$ on the basis of which we have committed to increase our "on budget" support and decrease "off budget". We are not at 50\% yet but we are approaching that level. So around $30 \%$ of our funding is "on budget" and that is mainly through the ARTF administered by the WB. The rest is channelled through civil society organisations, the UN and so on.

If you follow the link below, there is a lot of information about how to apply for funding and the mechanisms for accessing to funding from Global Affairs Canada.

http://www.international.gc.ca/development-developpement/funding-financement/fun-fin.aspx?lang=eng

1) Calls for Proposals: (see link below).

http://www.international.gc.ca/development-developpement/partners-partenaires/calls-appels/index.aspx?lang=eng

We do not have this call for proposals very often but we had a recent one in September 2015 for support for women and girls. The process is still on going and we hope to announce the results in January 2016.

\section{2) Partnering with a Canadian organization:}

We have an unsolicited proposals mechanism. It is always open and you can follow the guidelines and submit a proposal any time. The only limitation is that it is only for international or Canadian organisations, so Afghan NGOs have to partner with a Canadian organization and submit a joint proposal for funding. There are a few Canadian NGOs - Aga Khan Canada, Save the Children Canada, World Vision Canada - these are currently working in Afghanistan in different programmes in health and education. So that is the opportunity - if you have an idea and want to submit a proposal you can enter into partnership and submit a joint proposal.

3) Response to humanitarian crisis: Whenever there is a crisis in a country like Afghanistan, there is always a call for proposals which is opened. So those organisations or groups who have an expertise in emergency response they can take an opportunity to apply.

\section{4) Canada Fund for Local Initiatives (CFLI)}

This is a familiar mechanism to many of you and has been operation for a long time, previously based in Peshawar. It is shrinking in terms of funding unfortunately. It was managed by CIDA but has now been transferred from the development side of the Embassy to the political side of the Embassy. The Ambassador of Canada has discretion to approve funding. It advertises its call for proposals either in July or August every year. Project implementation timelines is between October and February. March is end of fiscal year so projects should be closed by then. There is a large distribution list managed by the Embassy so if you are not on the list you can contact my colleague below:

Audrey Loney: Audrey.Loney@interntional.gc.ca, 0701108856

\section{5) International Development Research Centre (IDRC)}

\footnotetext{
${ }^{6}$ Previously known as the Tokyo Mutual Accountability Framework (SMAF)
} 
This is also well known. Those organisations interested in research opportunities in Afghanistan or other countries can apply for development research work at a university in Canada or in a developing country.

http://www.idrc.ca/EN/Funding/Pages/default.aspx

\section{6) Diploma in Development Leadership}

This is a twenty week diploma programme for individuals or members it is well known. Timing is between July 18 and December 4, 2016, Coady International Institute, ST. Francis Xavier University

http://www.coady.stfx.ca/education/diploma/

7). Equitas - Annual International Human Rights Training Program - a comprehensive two-week training in Montreal, Canada

https://equitas.org/wp-content/uploads/2015/09/Information-package-IHRTP-2016-.pdf

\section{Advocacy}

In addition there is the advocacy role that the Canadian Embassy plays in the country to support the CSOs. Those of you involved in health know that the government has decided to transition service delivery in the health sector from the CSOs to the governmental side, so limiting the space of civil society organisations. The main health donors in the country were asked to comment on the concept paper developed by the Ministry proposing a transition from NGO service delivery to government service delivery. One of our strong comments was that NGOs have a lot of expertise in service delivery and strong relationships with the communities and they have access to remote areas. This expertise and knowledge should not be lost because government would like to transition. So one way or the other the government should think how to keep NGOs/CSOs engaged in the health sector if this transition happens. They should not simply disappear.

The next item is also as part of our advocacy role, you might know our Ambassador, Deborah Lyons, she is a very strong advocate for civil society groups especially for empowerment of women and girls and she is also engaged in different fora and in different events with government, donors and the international community, and always advocates for civil society groups. So that is the other role we play in terms of supporting civil society.

\subsection{Embassy of Federall Republic of Germany - Franziska Johanna Albrecht}

I apologise that my economic development and cooperation colleagues were otherwise engaged, I am from the protocol and press department, so I hope I can tell you what Germany is doing at the moment. We have two government institutions that provide funding for various projects - one is the Ministry for Development and Cooperation and the other is the Federal Foreign Office. They both have representatives working here in Afghanistan.

\section{1) NGO funding from German Ministry for Economic Development and Cooperation}

This is suitable only for German NGOs. Afghan NGOs can however gain access to this fund by partnering with German NGOs. This has happened successfully on past occasion. 
- Eligibility criteria:

- German private executing agencies (legal persons under private law) that are headquartered and conduct business in the Federal Republic of Germany

- Non-profit or charitable status is recognised under fiscal law and with at least three years of experience.

- At least three years working experience in cooperating with experienced partners in developing countries who are independent of the German executing agency. So Afghan NGO who wants to work need to find a German NGOs.

- Collaboration with one-person corporations is ruled out.

- Further information (guidelines as .pdf): http://sho.rtlink.de/guidelines-german-ngos

\section{2.) Foreign Office Funds}

- Foreign Office does not have as much money as Ministry of Economy Development but it does have quite substantial funds for Afghanistan in particular. They have supported substantial projects $\mathrm{GIZ}$ and KfW in the past as well as other German NGOs and different national NGOs and some Afghan NGOs. These have supported projects in rule of law, health, education, and women's projects - at the moment there is a gender studies programme implemented with one of the universities.

- Usually these are one year projects - German fiscal law very strict on this - sometimes they run for more than this but it is very rare.

- It is also very important that the support is project based only, it is not institutional support. There has to be complete information showing the project and also provide a list of project based staff, not staff who have been with the NGO before. This is a bit of a problem sometimes.

- We do not have regular calls for proposals; usually we do not need them as we have a lot of unsolicited proposals anyway. We usually get more proposals than we are able to fund, so the projects get prioritized. If you have something and you are interested to apply, send us a concept note and ask if there are funds available, and we will check with the Foreign Office. Yesterday we checked, they said that funds are mainly tied up for 2016 but there are some left.

\section{3) Small Grants Fund of the German Embassy, Kabul}

We also have small grants fund administered from the Embassy without Foreign Office involvement. The maximum amount is 25,000 Euros. There are specific criteria:

- Small projects that cannot be financed by local partner organization (NGOs, public authority, et. al.).

- The grant recipient and the local population should make their own contribution to the project - to the extent of their capabilities.

- The project should be designed in a way that necessary material assets can be bought in Afghanistan or in neighbouring countries but we prefer Afghanistan in order to help the local economy.

- Staff costs for skilled workers or transportation costs can be paid if the grant recipient or the local population cannot pay for them. There has to be a reasonable relation between these costs and the total costs of the project, so staff costs cannot be too high.

- Also for capacity building trainings expenses for room rents, technical equipment and trainer's salaries can be paid, but expenses for participants of the training (e.g. accommodation, meals ...) cannot be paid. 
- The project should not cause recurring costs (e.g. salaries, or for consumable materials like medicine, animal feed, fabric, paint etc.).

We did several of these projects last year with local NGOs both German and Afghan. For example a new laundry room in a hospital was funded to improve hygiene standards - the NGO provided the washing machines and we contributed the room. Another one was a kindergarten (nursery) in a school for smaller children. Or an environmental project just completed where an Afghan NGO was planting trees along roadsides. We provided four mobile water tanks to help water the trees for 10,000 Euros to prevent the trees dying. So this is comparatively small but has big effect on the community as the trees were planted by volunteers in the local communities. It can be any type of project really - education, environment, empowerment of women, health etc. We just wait for organisations to approach us but remember the German fiscal year ends in December, so if a project starts in November then we will be sceptical that it can be finished by the end of the year. So the best time to submit is now in January. So if you are interested we are looking forward to that.

\subsection{USAID’s Office of Democracy and Governance (ODG), Afghan Civic Engagement Program (ACEP)}

USAID was unable to attend the meeting. Details of their presentation are provided in Annex 6 of this report.

\subsection{Questions and Comments to the Donors Panel}

Comment: I have some suggestions. In terms of rejections of the proposals of local NGOs, the problem is with the capacity of local NGOs, therefore more must be done to strengthen their capacity. The big networks of CSOs must be a part of roadmap consultations. It will be good if donors give some workshops for CSOs networks, then the networks can provide those trainings to their members.

Question: Accessibility to funds and donors' offices is often difficult and processes need to be improved. Also the Dutch government had a good programme and support to the CSOs in Uruzgan in the past. But now it has stopped, what was the reason as this is humanitarian assistance?

Q: Regarding national human rights training programs, as a humanitarian actor we have many problems in getting visas. Are there any facilities for the human rights activists in 2016 to participate in such trainings? One problem is having to travel to Pakistan to get the visa and also the requirement to have a sum of 1000 dollars in the bank.

Q: Could you let us know exactly how donors coordinate between themselves?

Q: How do you ensure transparency both on donor side and the side of civil society?

EU: Answer - With regards to the problem of capacity and applications being rejected - what we will do in a more systematic way - whenever we launch a call for proposals is to provide an information session (and advertise widely) to make sure that lessons learned from previous applications are disseminated, the same way as we did today so that common mistakes are minimized. We will make sure we use of coordinating body networks especially for provincial levels to disseminate and to get information. For your rejected applications, we usually reply to all 
applications, unless they were submitted beyond the deadline. I do not know the specifics but please contact our team so that we can reply to all questions.

For transparency for EU applications we have at least three evaluators taking part in the process to ensure that there is a balance of views and everything is recorded and there are strict rules for the process.

DFID - On donor coordination a lot of coordination happens sectorally, so around health or education or women's rights rather than on broader levels across civil society. We have a number of processes to support transparency and accountability. For competitive bids we have transparent and accountable processes with independent panels assessing technical and commercial aspects of bids. On our website we also publish all our business cases, annual review, they are accessible to anyone. We have zero tolerance on corruption and place a lot of emphasis on technical and financial monitoring and audits.

Dutch Embassy - regarding the question of Dutch support to organisations in Uruzgan - we had the withdrawal of Dutch military forces from Uruzgan, and like other PRTS teams, we handed over the peace keeping mission to the Afghan Government. We have do have follow up with Afghan NGOs in the province to see how things are going. We invited the governor and officials to discuss how things were going. Our doors are open to NGOs from Uruzgan to come and see us exchange information and we can accept proposals for Uruzgan from all organisations with no limitations.

UNAMA: We are not a donor but we do provide coordination and facilitation for civil society organisations such as facilitating the establishment of the Civil Society Joint Working Group (CS-JWG) in 2010. We also set up the technical-level donor Civil Society Support Group (CSSG) which is a forum for civil society to brief the international community about civil society activities especially prior to international development conferences. Civil society can also request donor/international community support activities such as data collection to monitor and evaluate implementation of the government's Self-Reliance for Mutual Accountability Framework (SMAF).

Canadian Embassy: Answer - on the visa issue, it is not easy for Afghans to go to Islamabad or Delhi to apply for visa and there many applications that have been rejected. And we accept that it is a huge issue for Afghans who want to apply for Canadian visa. Our Ambassador can recommend a particular application to Delhi or Islamabad but she does not have control of the decision making. I agree this is a huge issue for Afghans applying for Canadian visas.

Regarding the donor coordination in health sector, there is a good forum called Health Development Partners Coordination Forum, which has set terms of reference and meets regularly on monthly basis. And currently Canada is the co-chair of that with WHO. One of the activities we do in the forum is advocacy and the other activity is information sharing to avoid duplication.

Comment: For better communication of donors each month or quarterly we should have coordination meeting with coordinating bodies, donors and UNAMA. This would be better.

Canadian Embassy: Answer - we have seven mechanisms for funding opportunities and only one requires an Afghan NGO to partner with a Canadian organisation. The rest are open for all. In terms of space for national organisations: Afghanistan is a pluralistic society now, there is a space and will be space in Afghanistan for civil society. CSOs, international and national are a part of democratic space which is created in this country. In terms of new NGOs, as 
long as you are registered, as long as you have the expertise in the area, as long as the employees you propose have the expertise, so it is not really matter if you are new or old.

DFID: Answer - on the programs of eliminating of violence against women, we have a mix of international and national partners and definitely support Afghan NGOs in that area. The space in civil society is important in programming and policy. Funding support overall is more competitive and CSOs should consider partnerships and coalitions where you have an added advantage with a broader group. In terms of new NGOs, we need to have 3 years of audited accounts so you may need to join with other partners to gain experience in initial stages. 


\section{Part 2 - Civil Society Joint Working Group}

Facilitated by Michael Steffens - EU

\section{Presentation of the Civil Society Joint Working Group, Ahmad Sear Lallee}

I will touch on 3 important things: first the structure of civil society joint working Group (CSJWG), secondly the Code of Conduct of the Mutual Cooperation Mechanism between government and CSJWG and thirdly the CSJWG plan and taking of decision for monitoring of Afghanistan government and international community commitments.

The CSJWG structure has a General Assembly (GA) and the GA has conducted an election and as a result of transparent election, 21 persons were selected to be CSJWG secretariat members. Umbrella Organizations are also member of this secretariat. After the selection of the Secretariat, the Kabul secretariats of CSJWG divided in to the committees based on the SMAF. Now the CSJWG has the following committees that are working inside the secretariat.

$1 \quad$ Improving Security and Political Stability;

2 Anti-corruption, Governance, Rule of Law, and human rights committee;

3. Restoring Fiscal Sustainability and Integrity of Public Finance and Commercial Banking committee;

4. Reforming Development Planning and Management and Ensuring Citizens' Development Rights committee;

5. Private Sector Development and Inclusive Growth and Development committee;

6. Development Partnerships and Aid Effectiveness committee;

7. Media relation committee;

8. Advocacy committee;

9. Government relationship committee;

10. Donor relationship committees;

11. Secretariat committee: is responsible for facilitating all the activities of the Kabul secretariat.

After the selection of the Kabul secretariat, the secretariat is responsible to establish secretariats at zone levels for other civil society organization working in the remote areas. The models are copied in each zones, so one secretariat has been established for the northern provinces in Mazar, one for Bamyan Province for the central highlands, the third one for Herat for the west, one in Nangarhar for the East, one for Paktia (Gardiz) for South and one secretariat will be established for Kandahar.

To include all CSOs for CSJWG on monitoring of the government and international commitment, the area of intervention has been selected based on the code of conduct for the Mutual cooperation between CSJWG and government. The first area that we have mentioned in the code of conduct for the mutual cooperation is cooperation, and the second is capacity building, the third one is monitoring, the fourth one is advocacy and also public awareness. The government have committed to support CSJWG in all mentioned areas of the interventions and committed to inform all governmental institutions in Kabul and provinces to support CSJWG, and CSOs.

The objective of coordination is:

- To strengthen coordination between the members of the CSJWG for joint working is the shared values; 
- To strengthen coordination between CSOs and government;

- To strengthen coordination between National and International organizations and institutions who are working for shared values;

Something that we want to deliverer under the coordination intervention is:

- Establishing of Kabul CSJWG secretariats is completed;

- Establishing of the CSJWG regional secretariats is ongoing;

- Developing a code of conduct of mutual cooperation of civil society and government has been developed and signed

- Conducting regular meetings of the secretariat is ongoing ;

- Making a database to list all CSOs to know about all areas of working and the geographical area of CSJWG;

The second intervention area is Capacity building:

The objective is to build the thematic capacity of six committees based on the Self-Reliance Mutual Accountability Framework (SMAF) commitments through trainings. This will enhance the institutional capacity building of the members to develop an action plan, monitor plans and advocacy plans in all these needed documents

Need of the committees under this area of intervention

- Trainings on relevant themes for each committee: we need to design the trainings and workshops for the committees on the relevant teams to enhance the knowledge and capacity of that committee

- $\quad$ Hiring experts to work practically with the committees: we need a person to have experience to practically support the committees for developing action plans and perform the activities

- Developing action plans of each committees: is one of our needs that we want to work on it and still we are thinking how to support the committees to enable them to develop the plans

- $\quad$ Training the committee members based on the action plans and after developing the plans once again we need to have some sessions, trainings for the member organizations in Kabul and regions to introduce and capacitate them how to use the action plans and how to implement the action plans

The other intervention area is monitoring which is very important.

The objective is to establish a monitoring mechanism; we have to think how to monitor the all commitments based on the SMAF documents.

To monitor the government plans based on the indicators of SMAF, we want to make mechanism and monitoring plans to put all the outputs and the indicators of the SMAF and trains the committees to use this table for monitoring of the SMAF indicators and also.

To provide monitoring reports and also after the monitoring and data collection, the secretariat has plans to provide monitoring reports and launch it for relevant organizations and to the government.

The other need of the committees under this area of intervention is: 
- Technical support to develop the monitoring mechanism;

- Receiving training on how to collect data and use the data for monitoring report

- Supporting the committees to make their plans and other needed documents;

We need these three to make the committees and enable the committees to fulfil their responsibilities,

\section{Objectives of Advocacy is one another area of the intervention}

To keep the government accountable towards its commitments through:

1. Launching monitoring report with specific recommendations;

2. Meetings with relevant ministries and departments to ask about the plan and progress;

3. Influencing on law making and policy making process;

4. Conducting campaigns;

5. Statements and press conferences;

\section{Objective of public awareness}

To increase access of citizens to information through:

1) CSJWG Facebook's

2) Reports;

3) Outreach materials;

4) Media engagement.

The secretariat in Kabul is working on a monitoring table which contains data on the SMAF outputs and indicators relevant to the SMAF commitments. Each committee will be trained in how to use this table to help them monitor and report on the SMAF.

Mrs. Humaria Saqeb is responsible for running and coordinating the activities of the secretariat as well as organising secretariat efforts to conduct elections at zone levels, to identify CSOs and making plans to establish secretariat representation-at the zone levels, and to- link the CS-JWG secretariat and members in Kabul with their counterparts at the sub-national level as specified in the agreement signed by the Government and CS-JWG to have a Mutual Cooperation Mechanism. Since signing that memorandum of understanding, we in the CS-JWG have been meeting regularly the Government's Administrative Office of the President. Mr Wasiq, from that office, is here and he has been very cooperative with the CSJWG. He and his office are always informing and inviting us for consultations in order to discuss important issues. We are in contact with them and working together on plans for joint efforts to raise public awareness through the media as well as to inform the government of the views and needs of the people so that the government can respond accordingly.

\section{Panel Discussion}

A panel was invited on to the stage of civil society and government representatives to give brief statements:

- Mrs. Humaira Saqeb, the head of CSJWG secretariat and head of Afghan Civil Society Network for Peace and Director of Afghan Women's News Agency (AWNA),

- Mrs. Freshta Karimai, the director of De Qanon-Ghukhtunkai (DQG) and member of CSJWG secretariat 
- Mr. Wasiq, Director of Political, Social and Culture Relations of the Administrative Office of the President of Islamic Republic of Afghanistan,

- Mr. Ahmad Seyar Lalee, deputy of Civil Society and Human Rights Network (CSHRO) and member of CSJWG secretariat, on the committee of good governance and human rights of CSJWG.

Mrs. Freshta Karimi - The CSJWG is known by the government and international community. It is a very good platform for donors and government to together and to monitor and implement different activities not only in Kabul but also in the provinces.

Previously only one organization was running the secretariat, but recently a decision was taken to change the structure of secretariat from one organization to 21 organizations. In September 2015 the CSJWG signed the Mutual Cooperation Mechanism (MCM) agreement with the government. We are also involving other CSOs in the CSJWG structure and working closely in the other provinces to collect data from civil societies, so they can join with the CSJWG. We were very involved in the issues surrounding the fall of Kunduz in October 2015. The CSJWG is closely working with the CSOs, those who are in risks to bring them in Kabul, and we were able to provide them services and also we are involving with other committees established by the government. Also we were able to introduce the civil society representative for those committees such as committee on implementation of the access to information law and we were able to introduce our representatives to the election committee, so these are the main achievements that we have made so far.

Comment: - why did the CSJWG sign an MoU? What was the need?

Answer: During the London Conference in December 2014, the Afghanistan government committed to developing relations with civil society. After this, the government, particularly the President requested the CSJWG to sign an MoU with them to see cooperation increased.

Mr. Lalee - In addition before going to London Conference, CSOs have been facing a lot of problems, including access to information. We wanted to sign the MoU to enable CSOs to better make advocacy plans, capacity building plans and improve relations with the government in Kabul.

Question: Can the government representative, Mr Wasiq, give us an update on the next steps from the government side.

Answer: Mr. Wasiq - Thank you for organising such a good event. With regard to cooperation and coordination, Afghanistan is facing a lot of problems. Today we believe in the benefits that strong cooperation between CSOs, government and private sector have. We encourage them to learn from each other and to share their expertise.

The MoU has been signed between the secretariat of the CSJWG and government in order to share information between the government and the civil society. In the past civil society has tried together with the government to bring peace. We have put some steps together with the CSJWG secretariat to see which organizations are active in peace processes and conflict resolution. We are looking to see how we can bring these organisations together with the High Commission of Peace.

It is mentionable that there are some national values that are not negotiable or going to be broken. Those values have been considered in the Memorandum of Understanding that were signed in the peace process and based on 
the government's law, such as the rule of law, Islamic values, international conventions, women's' rights, human rights child rights, freedom of media, freedom of expression, democracy non-discrimination, impartiality etc.

I would like to thank the international community for their continued support of Afghanistan. I do recommend some small issues, like coordination of donor efforts. I have seen one school built next to another one - this is a duplication of efforts. Another example here in Kabul there is need for schools for girls but nobody is taking care about that, so most of the families are not sending their girls to the schools because that is only a mixed school or it is too far away from their homes. Therefore I recommend attention should be paid to these priorities. So there should be money spent based on the priorities and close cooperation and coordination among yourselves and the government of Afghanistan.

\section{Questions and answers raised by the participants}

UNAMA: Question: Are you also talking about what the government and CSJWG can do to publicize this mutual cooperation mechanism at national and provincial levels to get agreement from everyone?

Mr. Wasiq: Yes, everybody knows this cooperation and mutual understating has already started and we will go to the media to publicize it and also we will urge subnational levels authorities to accept and practice these ideas at sub national level as well.

Q for Humaira Saqeb: Do you have any plan to share information and reports of CSJWG, like MoU with civil society organizations or not?

Mr. Lalee - Yes the CSJWG has specific plan for launching reports and activities with CSOs and including the other CSOs who are not member of the CSJWG. We plan to establish meeting with all of the CSOs. We have a Facebook page for CSJWG, the report is shared on Facebook and we have plan to send the report through email for CSOs and we are sending the reports to all CSOs. Also we have a plan to train the secretariat in the regional levels to make a specific mechanism for sharing information of the activities for the CSJWG, Government and the other CSOs which will happen every six months.

Mr. Wasiq mentioned that, the government is not going to push the CSOs to do something for the government, now they have their own rights to make their own efforts and this agreement has been signed to bring cooperation and coordination and sharing the information between and nothing else

Question to CSJWG secretariat - As the NGO community is part of civil society, were there comments incorporated into the MoU?

Mr. Lalee: Answer - As we mentioned in the presentation the CSJWG is not the representative of all types of civil society in Afghanistan, we have a group of CSOs that we have shared values and we have discussed on this values make the strategies that how to work with CSOs and how to cooperate with the government. As Mr. Wasiq mentioned, the signing of MoU with the CSJWG and government cannot impose any thing on the CSOs and there is a set of values that are respected by both parties. We still hold our independence and work together with civil society to monitor the implementation of plans and the commitments of the government and inform Afghan citizens of the situation and progress of the activities that government is doing. 
Mr. Freshta Karimi shared two examples - When the government requested civil society to introduce their 3 members to the election committee of the commissioners, there was no influence from the government. They have completely independently conducted their election and they have selected their representatives the 3 different parts. Like the media, women and election organizations have introduced their members to the government. The same for the Senior Officials Meeting were during our preparation of the position paper and when we were introducing our representatives there was no influence from the government side although we already have this agreement. Hence we have done all our elections and introductions of representatives independently.

Ms. Fiona Gall - question for both Government and CSJWG - Do you feel that the trust and cooperation is possible between both groups because when we talk about holding government accountable that can be quite difficult. So how do we implement this process together?

Q - How will this Mechanism affect the poor farmer in remote central Highlands?

Mr. Wasiq - With regards to government accountability, it must be noted that we have choses areas, or sectors, where we can have an impact on government accountability and where we can most successful interact and cooperate with the government.

With regards to the question on how this initiative will reach the poor farmer. Farmers are a part of civil society. Civil society activists are working with communities and have access to the people and therefore need to transfer the knowledge to people in the community.

Mrs. Freshta answer to question above - under the new structure of the CSJWG, we have 6 technical committees, and beside that we have other committees like advocacy committee. Each committee will have their own plans for engaging with the government in Kabul but also at sub-national levels. 


\section{Annex One - European Union (EU)}

\section{Current support}

- Competitive "calls for proposals", local or global

- In 2015, the EU in Afghanistan managed 67 grant contracts implemented by NGOs/CSOs, for a total amount of EUR 101 million

- $\quad$ Average grant size = EUR 1,5 million (EUR 700,000 under CSO-LA and EIDHR)

- Indirect support through other programmes
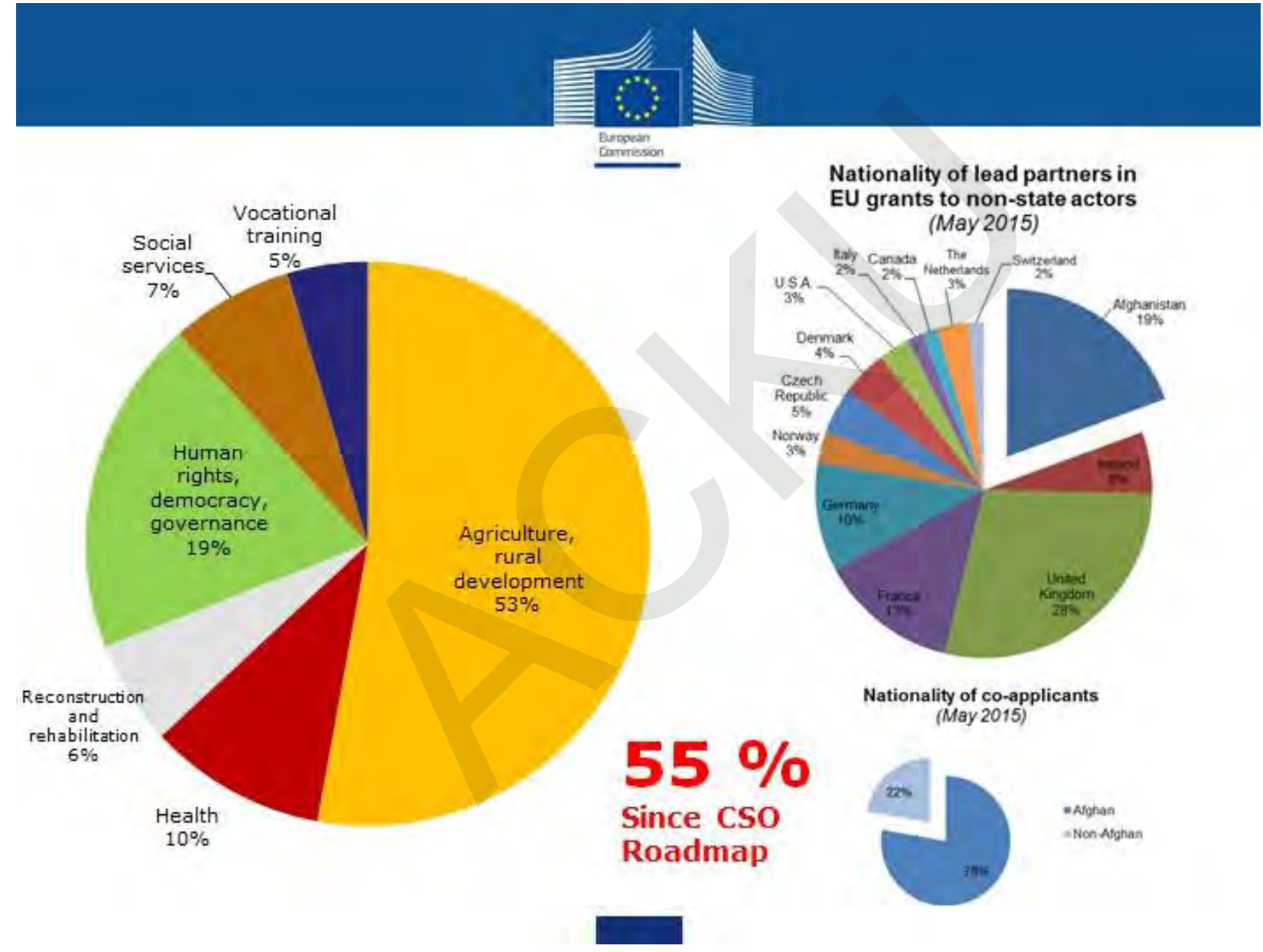

\section{CSO Roadmap and Future Plans}

- CSO Roadmap priorities:

- 1) more consultation when setting funding priorities

- 2) reach grassroots and constituency-based organisations beyond Kabul

- 3) publicly and openly accessible information on results

- 4) sustainable interventions beyond the lifetime of individual projects

- 5) improved coordination between donors 
- 6) strengthen ability of civil society to hold government into account

To see the roadmap for engagement of civil society in Afghanistan visit the link bellow. http://www.eeas.europa.eu/delegations/afghanistan/documents/eu afghanistan/2015-9-6-euroadmap-for-engagement-with-civil-society-in-afghanistan-final en.pdf

\section{Tips for EU calls for proposals}

Common mistakes in applications (out of 73 concept notes in two recent calls, 31 were rejected for the following reasons $-42 \%$ ):

- Out of minimum or maximum funding limits (8) $\mathbf{- 1 1} \%$

- Co-funding ceiling exceeded (8) - $\mathbf{1 1} \%$

- Missing documents in application (7) $-9.6 \%$

- Failure to include a co-applicant (5) $-6.8 \%$

- Out of minimum or maximum duration limits (1) $-\mathbf{1 . 4} \%$

- Failure to upload audit reports/latest accounts on PADOR (1) - $\mathbf{1 . 4} \%$

- Mistake with simplified costs/lumpsums (1) $-\mathbf{1 . 4} \%$

\section{A new online application system}

This is a solution for the mistakes in application, and it is strongly recommended to go to this website and there is an e-learning training on how to use this system. Because there will be no more old application system.

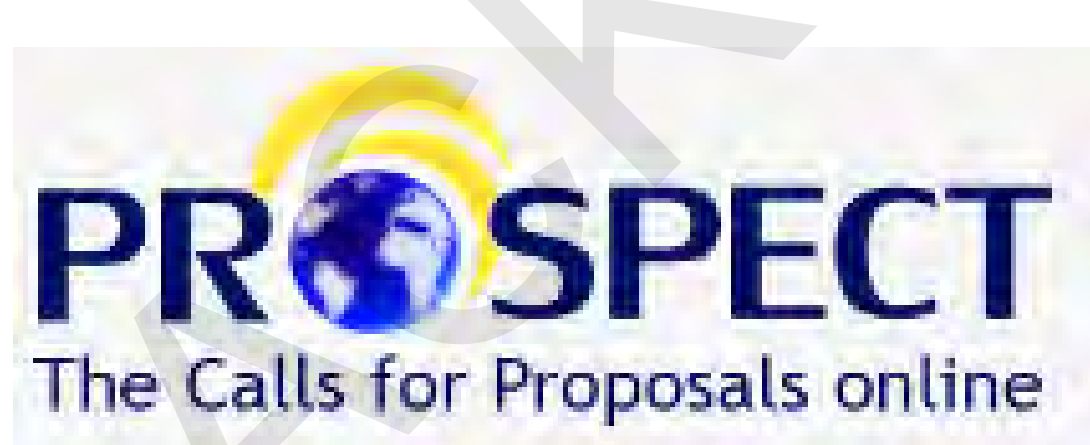

https://ec.europa.eu/europeaid/prospect 


\section{Annex Two - Department for International Development (DFID)}

\section{UK Support to Civil Society in Afghanistan}

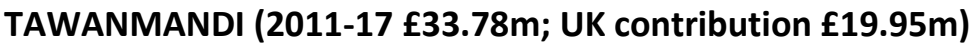

- Core and project grants to over 80 CSOs

- Thematic areas: Anti-corruption, access to justice, peace building, media and human rights

- Organisational development and capacity building

- Sector Core Working Groups

- TA support for advocacy (2016-17)

\section{Humanitarian Program (2014-18 $£ 80 \mathrm{~m})$}

- Capacity building of humanitarian NGOs (over 40 national) and strengthening co-ordination and engagement in humanitarian systems ( $€ 2 \mathrm{~m})$

- Resilience Consortium (led by Afghan Aid) for service delivery in Northern areas

- Common Humanitarian Fund (CHF) - delivery of services based on need; implemented by international and Afghan NGOs

\section{Girls Education Challenge Fund ( $₫ 49.5 \mathrm{~m}$ 2013-17)}

- Community based education for girls and boys in marginal areas

- 4 sub-projects implemented by INGOs; in partnership with community school management committees

\section{Afghanistan Reconstruction Trust Fund}

- Service delivery (e.g. health, education, NSP)

\section{Women's Rights Programming}

- Support to INGOs and national NGOs on violence against women prevention, protection and response; women's economic empowerment

\section{Human Rights and Democracy Fund}

- Global programme providing support to national NGOs

- Ongoing programmes

- Strengthening civil society capacity and advocacy in select areas (e.g. Security Sector, Extractive Industries)

- subject to approval

- Human Rights Democracy Fund (tbc)

- EU programming for civil society

- Policy: Road to Warsaw and Brussels

- Strengthening organisational capacity:

- Capacity for financial management and controls

- Capacity for strategic planning and advocacy

- Sustainability and business planning

- Monitoring and Evaluation 
- Opportunity of collaboration and co-ordination within sectors for wider impact/advocacy

- Among CSOs, and with other actors but can be challenging!

- Targeting specific policies/agendas

- Differential needs and capacity of smaller, rural organisations

- Security challenges and costs

- Consider and budget resources and training needs at outset

- Need for stronger donor co-ordination 


\section{Annex Three-Embassy of the Kingdom of the Netherlands}

In general, there are two sources of funding for Afghan and/or International NGOs working in Afghanistan within Dutch Ministry of Foreign Affairs and ministry of Foreign Trade and development Cooperation; one is provided directly by the ministry in the Hague (central funding) e.g. Reconstruction Program, FLOW and Addressing Root Causes Fund, and another is provided and managed by the Dutch Embassy in Kabul.

\section{The Netherland Embassy's fund}

The Dutch Embassy in Afghanistan has its own focus area to support the development goals of the Netherlands just like other embassies/missions. Current Focus area had been narrowed down in 2014 to the field of security and the rule of law, with special attention for women's rights and gender. We believe the civil society organisations in Afghanistan and Dutch co-financing partners will play an important role in implementing projects within the mentioned-above focus area.

Hence besides supporting programs executed by UN agencies like ELECT, EVAW special fund, APRP, we support Dutch, international and Afghan CSOs like APPRO, CORDAID, EPD, and TAF. For all of them capacity development of the implementer and sub-contracting CSOs are included as a substantial component.

By completion of the Dutch Reconstruction missions in Uruzgan, the Netherlands has started integrated police training mission in Kunduz. Hence we have preference for Northern provinces in particular Kunduz.

Central Funding: There are different thematic frameworks. Of them the followings are important.

\section{Addressing Root Causes Fund (2016-2021)}

The Ministry of Foreign Affairs will introduce a NGO-fund aimed at addressing root causes of instability, conflict and forced migration in a group of countries including Afghanistan.

A call for proposals will be published in January indicating all required documents.

The fund will be open for Dutch, international and local NGOs.

Until the date of publication, the embassy will not provide any further information.

\section{Funding Leadership and Opportunities for Women-FLOW (2016-2020)}

The programs funded by FLOW aim to create opportunities for women and girls and foster a transformation towards an enabling environment in which women's rights are better protected. At both local and national levels the programs will contribute to sustainable, inclusive development and to fight against poverty and the lack of equal rights for women and girls.

Of the nine selected programmes, Women for Women International (Wow) program "Engaging women as agents of change against gender-based violence and poverty" will implement in Afghanistan.

\section{Reconstruction Tender (2012-2015)}


The main objectives of the programs funded under Reconstruction Tender are improving human security in relation to public safety and security, legitimate government, and peace dividend.

\section{Nuffic Tailor Made Training (TMT)}

Program offered as part of the Netherlands Fellowship Program (NFP) run by Nuffic, the Netherlands organization for international cooperation in higher education. NFP promotes capacity building by providing training and education for professionals in development countries including Afghanistan. A tailor-made training course is designed to meet specific needs of a requesting organization. The TMT is specifically meant to enhance the overall functioning of an organization by training a selected group of its staff members.

The program is open to a broad range of organizations in 51 NFP countries, from education institutions, research institutes and ministries to NGOs and small and medium-sized enterprises (SMEs). Afghan NGO's or Afghan government or education organizations (i.e. MoJ, AIBA, SC, AGO, universities, local partner organizations), do qualify for the program. It is open for applications in the field of security and rule of law, with special attention for women's rights and gender.

To get more information on how to apply for the Embassy's fund, please contact kab@minbuza.nl 


\section{Annex Four - Embassy of Canada - Global Affairs Canada}

\section{Funding for International Development Projects:}

Global Affairs Canada's funding amount is around two hundred and thirty million Canadian dollars for the next three years starting from 2015 to 2017. This is the overall amount that is allocated for Afghanistan and there are four priority areas which Global Affairs Canada operating. This is health, Education, humanitarian response and human rights and women rights.

There is a lot of information in the bellow link about how to apply for funding and the mechanisms for accessing of funding from global affairs Canada

\section{http://www.international.gc.ca/development-developpement/funding-financement/fun-fin.aspx?lang=eng}

i) Calls for Proposals: to see Calls for Proposals, please visit the link bellow.

http://www.international.gc.ca/development-developpement/partners-partenaires/callsappels/index.aspx?lang=eng

ii) Partnering with a Canadian organization: Local NGOs can be a partner with a Canadian organization and they can submit a joint proposal for funding.

iii) Response to humanitarian crisis: when there is a crisis in Afghanistan there is always a call for proposals.

\section{iv) Canada Fund for Local Initiatives (CFLI) Max 38K}

CFP in Jul or Aug, Project implementation timelines Oct - Feb, Circulation list

Audrey Loney, Audrey.Loney@interntional.gc.ca, 0701108856

v) International Development Research Center (IDRC)

Researchers and students pursuing international development research work at a university in Canada or in a developing country

\section{http://www.idrc.ca/EN/Funding/Pages/default.aspx}

\section{Diploma in Development Leadership}

July 18 - December 4, 2016, Coady International Institute, ST. Francis Xavier University

http://www.coady.stfx.ca/education/diploma/

\section{vi). Equitas - International Human Rights Training Program}

https://equitas.org/wp-content/uploads/2015/09/Information-package-IHRTP-2016-.pdf

In terms of the advocacy role which Canadian embassy plays is to support the CSOs. The government is trying to have transition of the health sector from the CSOs to the governmental side, we had advocacy in this case that CSOs have a lot of expertise and relationships with the communities. 
For any questions and further information regarding Canadian Embassy funding's and above mentioned programs, contact Mr. Nasir Ebrahimkhail:

Nasir Ebrahimkhail, Senior Program Officer, Global Affairs Canada, Embassy of Canada

Nasir.Ebrahimkhail@international.gc.ca, 0799315336 


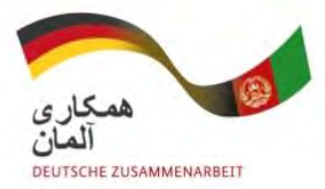

December 2015

\section{Funding opportunities for NGOs in Afghanistan}

\section{1.) NGO Facility of the German Ministry for Economic Development and Cooperation}

- suitable for German NGOs only

- eligibility criteria:

- German private executing agencies (legal persons under private law) that are headquartered and conduct business in the Federal Republic of Germany

- Non-profit or charitable status is recognised under fiscal law and who have at least three years of experience.

- At least three years working experience in cooperating with experienced partners in developing countries who are independent of the German executing agency.

- Collaboration with one-person corporations is ruled out.

Further information (guidelines as .pdf): http://sho.rtlink.de/guidelines-german-ngos

\section{2.) Small Grants Fund of the German Embassy, Kabul}

- max. amount: 25.000 Euros

- eligibility criteria:

- Small projects that cannot be financed by local partner organizations (NGOs, public authority, et. al.).

- The grant recipient and the local population should make an own contribution to the project - to the extent of their capabilities.

- The project should be designed in a way that necessary material assets can be bought in Afghanistan or neighboring countries.

- Staff costs for skilled workers or transportation costs can be paid if the grant recipient or the local population cannot pay for them. There has to be a reasonable relation between these costs and the total costs of the project. 
- For capacity building trainings expenses for room rents, technical equipment and trainer's salaries can be paid. Expenses for participants of the training (e.g. accommodation, meals ...) cannot be paid.

- The project should not cause recurring costs (e.g. salaries, or for consumable materials like medicine, animal feed, fabric, paint etc.). 


\section{Annex Six - United States Aid for International Development (USAID)}

USAID's Office of Democracy and Governance (ODG) - Afghan Civic Engagement Program (ACEP)

ACEP Presentation for Donor Workshop hosted by European Union (EU) at the EU Delegation to Afghanistan

\section{Project Overview:}

A strong civil-society and a robust independent media are essential components of a healthy democracy. USAID's Afghan Civic Engagement Program (ACEP) strengthen the role and viability of civil-society in Afghanistan by providing technical assistance, capacity building, and grant support to civil-society and independent media organizations nationwide.

The ACEP is a five-year program awarded to Counterpart International and its partners, Internews Networks, International Centre for Non-for-Profit Law (ICNL) and the Aga Khan Foundation in December 2013. The ACEP goal is to promote civil society and media engagement that enables Afghan citizens to influence policy, monitor government accountability, and serve as an advocate for political reform.

\section{ACEP Objectives/Program Areas:}

- Regular CSO engagement with government on policy and advocacy issues.

- Increase CSO and media thematic expertise in democracy and governance.

- Expand civic engagement.

- Improve access to independent news and public affairs information.

- Increase CSO organizational capacity.

- Crosscutting emphasis is placed on issues of gender, youth, and anti-corruption efforts throughout activities.

\section{Regular CSO Engagement with Government}

Support civil society engagement with government to increase CSOs' ability to advocate for policy priorities, activities include

- Supporting and strengthening the legislative working groups.

- Supporting local CSOs and convening community dialogues.

- Ensure women and youths participate in political process and providing women's empowerment and youth activism grants.

- Assisting citizen monitoring and reporting of government performance and service delivery as well as reduce corruption.

- Supporting the Emerging Civil Society Leaders and broaden youth political participation.

- Supporting the civil society sector in Afghanistan through the Civil Society Joint Working Group (CS-JWG).

\section{Increased CSO and Media Thematic Expertise}

Increase CSOs' and media thematic expertise in democracy and governance, activities include:

- Helping CSOs deepen their research capabilities and technical area expertise. 
- Supporting the creation or strengthening of CSO networks based on sector, issue, and/or geography.

- Facilitate sector CSO clusters for experience exchange - international exchange visits.

- Helping CSOs improve their legal enabling environment and image within their communities.

\section{Expand Civic Engagement}

Supporting the civic engagement activities, which include:

- Encouraging elections participation through small grants to CSOs for increasing awareness of electionsrelated issues and advocating citizen engagement.

- Focusing on general civic education topics related to citizens' roles and responsibilities in a democracy, and encouraging raised voices on issues of concern to individual communities.

- Conducting civic education sessions for the Afghan citizens at the community levels and support community activists as civic educators.

- Promoting CSO political participation and engage citizens at community, district and provincial Levels through civic learning, dialogues and action.

\section{Improved Access to Independent News \& Public Affairs Information}

Improve access to quality, independent news, activities include:

- Supporting media sector advocacy and policy reform.

- Increasing journalistic professionalism through trainings, particularly on reporting on issues of governance, organized sector discussions, and sponsoring internships.

- Supporting the public interest programming on civic participation and social issues through outlets such as Salam Watandar and Pajhwok News Agency.

- Improve communication and outreach skills of citizens through Multi-media centers.

- Supporting Nai Media Organization to empower local independent media and promote freedom of expression as well as support the sustainability of media outlets.

\section{Increased CSO Organizational Capacity}

Increase CSOs' organizational capacity through institutional support grants to key partner organizations with higher levels of capabilities who, in turn, mentor lesser developed CSOs at the grassroots level.

Supporting the AKF in establishing the Afghan Institute for Civil Society (AICS), which serve as an institute specifically for the certification of Afghan CSOs and to raise the credibility of civil society actors/sector.

\section{ACEP Contact Information:}

\section{Stephen F Herbaly}

Team Leader Civil Society and Media, USAID/Afghanistan

E-mail: sherbaly@usaid.gov Telephone: +93702029 198

\section{Niaz Gul Afghanyar}


Program Management Specialist, Civil Society and Media Team , USAID/Afghanistan

E-mail: nafghanyar@usaid.gov Telephone: +93 700279168

\section{Youssef Abdel Khalick}

ACEP Chief of Party (COP), Counterpart International, Inc.

E-mail: ykhalick@counterpart.org, Telephone: +93 796191019

\section{Ramin Nouroozi}

ACEP Deputy Chief of Party (DCOP), Civil Society and Media Team , Counterpart International, Inc.

E-mail: rnouroozi@counterpart.org, Telephone: +93797106072 


\section{Annex Seven- List of Participants}

\begin{tabular}{|c|c|c|c|}
\hline No & Name & Position & Agency \\
\hline 1 & Luc Verna & Head of office & $\mathrm{ECHO}$ \\
\hline 2 & Mario Giuseppe Varrenti & Head of section Governance and Accountability & EU \\
\hline 3 & Maurizio Cian & Head of Cooperation & EU \\
\hline 4 & Michael Steffens & Human Rights, Civil Society and Gender & EU \\
\hline 5 & Nasir Ebrahimkhail & Senior Program Officer & Canadian Embassy \\
\hline 6 & Somaia Nezami & Senior Policy officer & Dutch Embassy \\
\hline 7 & Franziska Johanna Albrecht & Protocol \& Press Office & German Embassy \\
\hline 8 & Omaid Sharifi & Programme Manager & Tawanmandi/British Council \\
\hline 9 & Sharon Hart & Administration Manger & Tawanmandi/British Council \\
\hline 10 & Shaker Sayar & National Programme Officer & Swiss Cooperation Office \\
\hline 11 & Mélanie Büsch & Programme Officer & Swiss Cooperation Office \\
\hline 12 & Mia Gul Wasiq & Director of Political, Cultural and Social Relations & Administrative Office of the President \\
\hline 13 & Katherine R. Blanchette & UNAMA Donor Coordination & UNAMA \\
\hline 14 & Gabrielle Dennis & Civil Affairs Officers & UNAMA \\
\hline 15 & Mohammad Nafi Frozanfar & Civil Affairs Officers & UNAMA \\
\hline 16 & Fiona Gall & Director & ACBAR \\
\hline 17 & Najibullah Tajali & Deputy Director & ACBAR \\
\hline 18 & Kimberley Ogonda & Advocacy Manager & ACBAR \\
\hline 19 & Mathilde Vu & Twining Manager & ACBAR \\
\hline 20 & Jawid Ahmad Omari & Information Officer & ACBAR \\
\hline 21 & Amanullah Jawad & ACBAR Chairman & NPO/RRAA \\
\hline 22 & Wendy Barron & ACBAR Vice Chair & CFA \\
\hline 23 & Stefan Recker & Steering Committee ACBAR & Caritas Germany \\
\hline 24 & Mr. Walayat Shah & +2 & ECW \\
\hline 25 & Dr Mir Abdul Baqi Ghubar & se & COFA \\
\hline 26 & Ahmad Seyar Lalee & Human Rights Officer & CHSRN \\
\hline 27 & Ahmad Fahim Hoshmand & 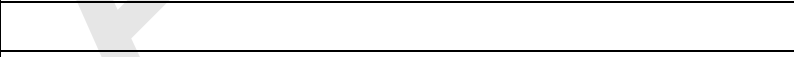 & AWN \\
\hline 28 & Roshan Mashal & Networking manager & AWN \\
\hline 29 & Mohammad Mudaser & General Director & HUDA \\
\hline 30 & Tamana Farahmand & Director & SCAWO \\
\hline 31 & Sayed Fazlullah Wahidi & Chairman of ANCB & ANCB \\
\hline 32 & Baryalai Omarzai & Senior Advisor of ANCB & ANCB \\
\hline 33 & Inayatullah Niazi & Program Manager & WADAN \\
\hline 34 & Sayed Rahim Sattar & Program Coordinator of ANCB & ANCB \\
\hline 35 & Jan Muhammad & & SWABAC \\
\hline 36 & Sadiqullah Fahim & & $\mathrm{OHW}$ \\
\hline 37 & Attullah Khan & & ARPD \\
\hline 38 & Humaira Saqib & Director & AWNA \\
\hline 39 & Frishat Karimi & Executive Director & CSJWG \\
\hline 40 & Saiduddin Nezami & Director & CCD \\
\hline 41 & Noria Safi & & WCBDO \\
\hline 42 & Mohammad Wasim & & WCBDO \\
\hline 43 & Agiso Cosmas Obuya & Donor Relation Coordinator & Afghanaid \\
\hline
\end{tabular}

